\title{
Bernd Käpplinger, Steffi Robak, Sabine Schmidt-Lauff (red.), „Engagament für die Erwachsenenbildung. Ethische Bezugsnahmen und demokratische Verantwortung", Waxmann Verlag, Wiesbaden 2013
}

Tytuł recenzowanej pozycji w tłumaczeniu na j. polski „Zaangażowanie w edukację dorosłych. Etyczne odniesienia i demokratyczna odpowiedzialność" odzwierciedla w pełni postawę prof. Wiltrud Gieseke. Niniejsza książka to zbiór artykułów współpracowników, przyjaciół i uczniów prof. Wiltrud Gieseke z okazji Jej 65. urodzin. Zamieszczone w książce teksty odnoszą się do głównych obszarów badawczych W. Gieseke: emocji, kultury, profesjonalizacji, doradztwa, gender, badania programów i instytucji, które stały się tytułami kolejnych rozdziałów książki.

W. Gieseke przywiązywała od dawna duże znaczenie do roli emocji w procesach kształcenia. Swoje poglądy na ten temat wyłożyła w książce pt. „Uczenie się przez całe życie i emocje” (Lebenslanges Lernen Und Emotionen, 2007), bazując na wynikach badań neurobiologów, wskazała na znaczenie emocji w edukacji dorosłych i doradztwie. W recenzowanej publikacji R. Arnold i A. Pachner omówili różne znaczenia emocji w procesie kształcenia z punktu widzenia konstruktywizmu. Emocjonalny zwrot w edukacji dorosłych akcentują w swoim artykule R. Malloy i I. Schössler, zwracając szczególną uwagę na wyniki badań nad emocjami wśród menedżerów. R. Góralska i H. Solarczyk zreferowały stan badań nad emocjami w Polsce. Rozdział zamykają refleksje S. Dietel i U. Zimmermann na temat dobrych i złych emocji w edukacji oraz trudności w uczeniu się dorosłych.

Edukacja kulturalna zajmowała też ważne miejsce w pracy naukowej W. Gieseke. Zwieńczeniem badań w tym zakresie były badania komparatystyczne na ten temat w Polsce i w Niemczech. Podstawą empiryczną pro- 
wadzonych badań były ilościowe i jakościowe analizy programów instytucji edukacji kulturalnej. Do problematyki edukacji kulturalnej nawiązali w recenzowanej publikacji M. Fuchs, M. Fleige i I. Börjesson. W tekście „Edukacja kulturalna jako sztuka życia" M. Fuchs porównuje jej rozumienie w szkole i w edukacji dorosłych. Wspólnym punktem odniesienia jest „konstytucja subiektywizmu". M. Fleige analizuje temat kultury na przykładzie ewangelickiej edukacji dorosłych, a I. Börjesson przedstawia interpretacje zmiany znaczenia edukacji kulturalnej w kontekście pracy zawodowej.

Obszarem najdłużej eksplorowanym była w biografii zawodowej W. Gieseke profesjonalizacja edukacji dorosłych. Praca habilitacyjna „Habitus andragogów” (Habitus von Erwachsenenbildnern, 1989) i kolejne przyczynki na ten temat zmieniły podejście do tej problematyki, akcentując własności jednostki, tj. jej wiedzę, działanie i rozumienie, jak i społeczne uwarunkowania funkcjonowania instytucji oraz refleksyjną odpowiedzialność wyrastającą ponad partykularne interesy organizatorów edukacji. D. Nittel i J. Schütz interpretują w książce dedykowanej W. Gieseke różne aspekty zawodowych autocharakterystyk w kontekście napięć pomiędzy indywidualizacją, habitusem i społecznym uznaniem. A. von Hippel rozwija teorię profesjonalnego działania andragogów W. Gieseke, poprzez odniesienia do północnoamerykańskich modeli planowania w edukacji dorosłych. H. Pätzold tematyzuje zagadnienie profesjonalizacji edukacji dorosłych z perspektywy teorii systemów.

Rozdział „Doradztwo” otwiera tekst Ch. Schiersmann, która charakteryzuje profil kompetencyjny doradców w oparciu o szeroko zakrojone badania empiryczne prowadzone na zlecenie Narodowego Forum Doradców. R. Siebers pokazuje efekty zastosowania jakościowych metod do badania doradztwa w małych i średnich przedsiębiorstwach, identyfikując trzy typy doradztwa: certyfikacyjne, modernizacyjne i strategiczne. C. Maier-Gutheil analizuje doradztwo nie z perspektywy teorii kompetencji, tylko z perspektywy teorii różnicy, wskazując na kluczowe problemy i napięcia doradztwa. C. Enoch rozważa znaczenie krytycznej teorii doradztwa dla demokracji, odwołując się do kredo twórczości W. Gieseke - analizowania edukacji dorosłych jako formy demokratycznej odpowiedzialności, czemu dawała powielekroć wyraz w swoich publikacjach (m.in. Gieseke, Opelt, Weiterbildungberatung, 2004)

Wydany pod red. W. Gieseke w 2001 r. „Podręcznik edukacji kobiet” (Handbuch der Frauenbildung), prezentował na przełomie wieków aktualny stan wiedzy i badań w tym zakresie. W recenzowanej książce H. Nickel wychodząc od swojego tekstu z 2001 r. stawia pytania, na które w przyszłości 
powinna odpowiedzieć edukacja kobiet. Natomiast S. Rieger-Goertz prezentuje zgadanienie gender na przykładzie edukacji dorosłych katolickich organizatorów.

Ostatni rozdział tworzą teksty poświecone problematyce badania instytucji i programów edukacji dorosłych. I temu zagadnieniu poświęciła W. Gieseke wiele uwagi w badaniach empirycznych i refleksji teoretycznej [np. Gieseke (red.) Programmplanung als Bildungsmanagement?, 2000; Gieseke, Opelt, Erwachsenenbildung im politischen Umbrüchen. Programmforschung Volkshochschule Dresden 1945-1997, 2003]. O. Schäfter odwołuje się w analizie instytucji i programów do interakcjonizmu symbolicznego. K. Opelt przedstawia refleksje na temat przyszłości instytucjonalnej edukacji dorosłych. C. Pohlmann, M. Stimm i G. Lehmann przedstawiają przykłady zastosowania planowania w instytucjach edukacji dorosłych konfesyjnych organizatorów.

Autorzy zamieszczonych w książce tekstów analizują podjętą problematykę $\mathrm{z}$ różnych perspektyw teoretycznych i metodologicznych, zgodnie z zasadą - krzyżowania perspektyw - propagowaną przez W. Gieseke przez całe życie zawodowe. Pod pojęciem tym mieści się nie tylko różnorodność poglądów, co przede wszystkim kompleksowe analizy przedmiotu badań, pogłębione analizy realnych sytuacji i ugruntowane w danych scenariusze przyszłości. Celem tego typu działań jest pogłębione rozumienie, także niewygodnych kwestii, nie po to, aby znaleźć szybkie odpowiedzi i rozwiązania aktualnych problemów. Tym zasadom była W. Gieseke zawsze wierna w pracy zawodowej, której towarzyszyła aktywność społeczna, wypływająca z głębokiej etyki osobistej i zawodowej.

Książkę dedykowaną W. Gieseke kończą cztery osobiste teksty R. Süssmuth, D. Bennera, B. O. Höltersa i H. Stock pod wspólnym tytułem „Na pożegnanie", które pokazują jak dużą rolę odegrała W. Gieseke w nauce, polityce i praktyce oświatowej na wschodzie i zachodzie. Należy dodać, że W. Gieseke odegrała też szczególną rolę w polsko-niemieckim dialogu w dziedzinie edukacji dorosłych.

Kończąc recenzję życzę Prof. Gieseke jeszcze wielu lat owocnej pracy! 